\title{
A Geochemical Model of Fluids and Mineral Interactions for Deep Hydrocarbon Reservoirs
}

\author{
Jun Li, ${ }^{1}$ Raheel Ahmed, ${ }^{2}$ Qian Zhang, ${ }^{1}$ Yongfan Guo, ${ }^{1}$ and Xiaochun Li ${ }^{1}$ \\ ${ }^{1}$ State Key Laboratory of Geomechanics and Geotechnical Engineering, Institute of Rock and Soil Mechanics, \\ Chinese Academy of Sciences, Wuhan 430071, China \\ ${ }^{2}$ Dimue Technology Ltd. Co., Wuhan, China \\ Correspondence should be addressed to Jun Li; lijun2009s@gmail.com
}

Received 19 February 2017; Accepted 12 June 2017; Published 16 July 2017

Academic Editor: Keyu Liu

Copyright (C) 2017 Jun Li et al. This is an open access article distributed under the Creative Commons Attribution License, which permits unrestricted use, distribution, and reproduction in any medium, provided the original work is properly cited.

\begin{abstract}
A mutual solubility model for $\mathrm{CO}_{2}-\mathrm{CH}_{4}$-brine systems is constructed in this work as a fundamental research for applications of deep hydrocarbon exploration and production. The model is validated to be accurate for wide ranges of temperature $\left(0-250^{\circ} \mathrm{C}\right)$, pressure (1-1500 bar), and salinity ( $\mathrm{NaCl}$ molality from 0 to more than 6 mole/KgW). Combining this model with PHREEQC functionalities, $\mathrm{CO}_{2}-\mathrm{CH}_{4}$-brine-carbonate-sulfate equilibrium is calculated. From the calculations, we conclude that, for $\mathrm{CO}_{2}$ $\mathrm{CH}_{4}$-brine-carbonate systems, at deeper positions, magnesium is more likely to be dissolved in aqueous phase and calcite can be more stable than dolomite and, for $\mathrm{CO}_{2}-\mathrm{CH}_{4}$-brine-sulfate systems, with a presence of $\mathrm{CH}_{4}$, sulfate ions are likely to be reduced to $\mathrm{S}^{2-}$ and $\mathrm{H}_{2} \mathrm{~S}$ in gas phase could be released after $\mathrm{S}^{2-}$ saturated in the solution. The hydrocarbon "souring" process could be reproduced from geochemical calculations in this work.
\end{abstract}

\section{Introduction}

With the exploration and production of middle-shallow oil and gas reservoirs, the main oil/gas fields have come to the late stages of production. More and more intensive exploration work has been done on middle-shallow fields and it is not easy to achieve more breakthroughs. So, researchers are devoting more efforts in deep reservoirs (with depth more than $5000 \mathrm{~m}$ ). In China, the depositional environment is quite complex and special, so abundant hydrocarbon resources are possible. From the drilling evidence, an effective hydrocarbon reserve was found at more than $7000 \mathrm{~m}$ depth in China [1]. More and more research on deep layer hydrocarbon exploration has been carried out in recent years.

For deep hydrocarbon research, fluid-rock interaction is an important topic, as it will influence the fluid composition, physical and chemical properties, and transportation in porous media. The geochemical reactions are more active at locations with both gas and water, such as so-called gas-water transition zones $[2,3]$. When gas and water contact, both gas components and mineral will be dissolved in water, and many geochemical reactions could be triggered. In Sichuan basin, $\mathrm{H}_{2} \mathrm{~S}$ can usually be found from gas reservoirs. The existence of $\mathrm{H}_{2} \mathrm{~S}$ can be a result of geochemical reactions of dissolved hydrocarbon and sulfates. It is called "souring" process in some literature [2].

Numerical modeling of geochemistry is a useful tool to understand the mechanism of fluid-mineral interactions in deep reservoirs. PHREEQC is one of the most popular geochemistry software packages in hydrological applications [4]. The speciation in water associated with hundreds of chemical reactions can be dealt with. TOUGHREACT is a $3 \mathrm{D}$ reactive transportation simulator which is able to calculate geochemical reactions with similar database as PHREEQC [5]. This simulator has been widely used in $\mathrm{CO}_{2}$ geological storage and geothermal recovery projects. Both of the software programs are powerful for geochemical reaction analysis in porous media. However, for fluid-mineral interactions in deep reservoir, gas-brine phase partitioning and speciation should be carefully considered due to high temperature and pressure. In gas reservoirs, $\mathrm{CO}_{2}$ usually exists with quite a bit amount of hydrocarbons. So, in this work, we establish a 
mutual solubility model for $\mathrm{CO}_{2}-\mathrm{CH}_{4}$-brine systems, which is accurate for a pressure range of 1 bar to $1500 \mathrm{bar}$, temperature range of $0^{\circ} \mathrm{C}$ to $250^{\circ} \mathrm{C}$, and salinity range of 0 to $6 \mathrm{~m}$. With the solubility calculated by the model, PHREEQC is used to calculate equilibrium of $\mathrm{CO}_{2}-\mathrm{CH}_{4}$-brine-minerals (carbonates and sulfates).

\section{2. $\mathrm{CO}_{2}-\mathrm{CH}_{4}-$ Brine Mutual Solubility Modeling}

We assume that there are two fluid phases (i.e., aqueous phase and nonaqueous phase) existing at given temperature, pressure, and feed composition. $\mathrm{CO}_{2}$ or $\mathrm{CH}_{4}$ always dominates nonaqueous phase. Their solubilities in water and $\mathrm{H}_{2} \mathrm{O}$ content in nonaqueous phase are desired to be accurately reproduced by a thermodynamic model. In equilibrium state, for each component in the system (e.g., component $i$ ), the chemical potential in each phase should be equal. Then we have,

$$
\mu_{i}^{\mathrm{NA}}=\mu_{i}^{\mathrm{AQ}}
$$

For nonaqueous phase,

$$
\begin{aligned}
\mu_{i}^{\mathrm{NA}}\left(T, P, y_{i}\right)= & \mu_{i}^{\mathrm{NA}(0)}(T)+R T \ln f_{i}\left(T, P, y_{i}\right) \\
= & \mu_{i}^{\mathrm{NA}(0)}(T)+R T \ln y_{i} P \\
& +R T \ln \varphi_{i}\left(T, P, y_{i}\right)
\end{aligned}
$$

where $\mu_{i}^{\mathrm{NA}(0)}(T)$ stands for standard chemical potential of component $i$, which is the ideal gas chemical potential at the pressure of 1 bar $[6,7] ; y_{i}$ is mole fraction of component $i$ in nonaqueous phase; $f_{i}$ is fugacity and $\varphi_{i}$ is fugacity coefficient; $R$ is the gas constant $(8.31446 \mathrm{~J} / \mathrm{K} / \mathrm{mol})$; $T$ is temperature in $\mathrm{K}$; and $P$ is pressure in bar hereafter.

For aqueous phase,

$$
\begin{aligned}
\mu_{i}^{\mathrm{AQ}}\left(T, P, m_{\mathrm{sol}}\right)= & \mu_{i}^{\mathrm{AQ}(0)}(T, P)+R T \ln a_{i}\left(T, P, m_{\mathrm{sol}}\right) \\
= & \mu_{i}^{\mathrm{AQ}(0)}(T, P)+R T \ln \left(N w \times x_{i}\right) \\
& +R T \ln \gamma_{i}\left(T, P, m_{\mathrm{sol}}\right),
\end{aligned}
$$

where $\mu_{i}^{\mathrm{AQ}(0)}$ is the standard chemical potential of species $i$ in an ideal aqueous solution with a hypothetical unit molality [8]; $m_{\text {sol }}$ is the molality (in mole/Kg water, molal for short hereafter) of salt in the aqueous phase; $N w$ is the mole number of $1 \mathrm{~kg}$ water (55.508); $x_{i}$ is the mole fraction of species $i$ dissolved in the aqueous phase; $a_{i}$ is activity of component $i$ in aqueous phase; and $\gamma_{i}$ is activity coefficient of component $i$.

With (1) to (3), we have

$$
\frac{\mu_{i}^{\mathrm{AQ}(0)}-\mu_{i}^{\mathrm{NA}(0)}}{R T}=\ln \left(\frac{f_{i}}{a_{i}}\right) .
$$

Here, equilibrium constant is defined as $\ln \left(K_{i}\right)=\left(\mu_{i}^{\mathrm{AQ}(0)}-\right.$ $\left.\mu_{i}^{\mathrm{NA}(0)}\right) / R T$, so we have

$$
y_{i} \varphi_{i} P=N w K_{i} x_{i} \gamma_{i}
$$

TABLE 1: Parameters of $\mathrm{H}_{2} \mathrm{O}$ equilibrium constant in (6).

\begin{tabular}{lcc}
\hline Parameters & $T>373.15 \mathrm{~K}$ & $T \leqslant 373.15 \mathrm{~K}$ \\
\hline$a_{1}$ & $-9.0283127 E-1$ & $9.31063597 E 0$ \\
$a_{2}$ & $3.6492938 E-2$ & $-1.892867005 E-1$ \\
$a_{3}$ & $4.3610019 E-4$ & $1.307135652 E-3$ \\
$a_{4}$ & $-3.10936036 E-6$ & $-3.800223763 E-6$ \\
$a_{5}$ & $4.5920530 E-9$ & $4.0091369717 E-9$ \\
$a_{6}$ & $1.62996873 E 1$ & $2.2769246863 E 1$ \\
$a_{7}$ & $2.81119409 E-2$ & $-1.1291330188 E-2$ \\
\hline
\end{tabular}

The mutual solubility model of $\mathrm{CO}_{2}-\mathrm{CH}_{4}$-brine system is established based on the above principle. Equilibrium constants $\left(K_{i}\right)$, fugacity coefficients $\left(\varphi_{i}\right)$, and activity coefficients $\left(\gamma_{i}\right)$ should be properly carefully obtained.

2.1. Equilibrium Constants. For equilibrium constant of $\mathrm{H}_{2} \mathrm{O}$, we follow the work of $\mathrm{Li}$ et al. [7] with an empirical equation revised from Spycher et al. (2003):

$$
\begin{aligned}
K_{\mathrm{H}_{2} \mathrm{O}}(T, P)= & \left(a_{1}+a_{2} T+a_{3} T^{2}+a_{4} T^{3}+a_{5} T^{4}\right) \\
& \cdot \exp \left(0.1 \frac{(P-1)\left(a_{6}+a_{7} T\right)}{R T}\right) .
\end{aligned}
$$

The parameters $\left(a_{1}\right.$ to $\left.a_{7}\right)$ in (6) are all from Li et al. [7], listed in Table 1.

For equilibrium constants of $\mathrm{CO}_{2}$ and $\mathrm{CH}_{4}$, we follow the form of Mao et al. (2013):

$$
\begin{aligned}
\ln K_{i}= & b_{1}+b_{2} T+\frac{b_{3}}{T}+b_{4} T^{2}+\frac{b_{5} P}{T^{2}}+b_{6} P+b_{7} P T \\
& +\frac{b_{8} P}{T}+b_{9} P T^{2}+b_{10} P^{2} T+b_{11} P^{3}
\end{aligned}
$$

where $i=\mathrm{CO}_{2}, \mathrm{CH}_{4} \cdot b_{i}(i=1,2, \ldots, 11)$ are parameters. The parameters are determined from experimental data of gas solubility in aqueous phase. See Table 2 for more details.

2.2. Fugacity Coefficients. Peng-Robinson equation of state (PR-EOS for short [9]) is used from $\mathrm{CO}_{2}, \mathrm{CH}_{4}$, and $\mathrm{H}_{2} \mathrm{O}$ fugacity coefficients in the nonaqueous phase. PR-EOS is a classic two-parameter equation of state of cubic form. The related parameters of pure component systems can be found from the original work of Peng and Robinson [9]. For gas mixtures, mixing rule is used for the two parameters.

$$
\begin{aligned}
a & =\sum_{i} \sum_{j} y_{i} y_{j} a_{i j} \\
b & =\sum_{i} b_{i} y_{i}
\end{aligned}
$$

where $a_{i j}=\sqrt{a_{i} a_{j}}\left(1-\delta_{i j}\right)$ and $\delta_{i j}$ are binary interaction parameters of species $i$ and $j$. Binary interaction parameters for $\mathrm{CO}_{2}, \mathrm{CH}_{4}$, and $\mathrm{H}_{2} \mathrm{O}$ can be found in Table 3 according to Søreide and Whitson [10]. 


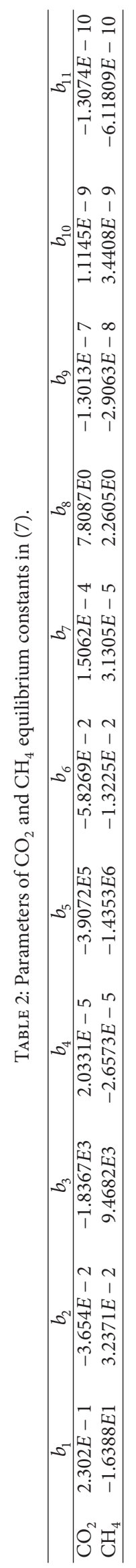


TABLE 3: Binary interaction parameter in PR-EOS.

\begin{tabular}{lccc}
\hline$\delta_{i j}$ & $\mathrm{H}_{2} \mathrm{O}$ & $\mathrm{CO}_{2}$ & $\mathrm{CH}_{4}$ \\
\hline $\mathrm{H}_{2} \mathrm{O}$ & - & 0.19014 & 0.485 \\
$\mathrm{CO}_{2}$ & 0.19014 & - & 0.1196 \\
$\mathrm{CH}_{4}$ & 0.485 & 0.1196 & - \\
\hline
\end{tabular}

2.3. Activity Coefficients. For activity coefficients, Pitzer model [11] was successfully used in gas-water-mineral modeling for high salinities in previous works [12-15]. Cations, anions, and interaction between particle pairs are considered to influence the component activity behaviors in aqueous phase. The activity coefficient equations are as follows:

$$
\ln \gamma_{i}=\sum_{c} 2 m_{c} \lambda_{i-c}+\sum_{a} 2 m_{a} \lambda_{i-a}+\sum_{c} \sum_{a} m_{a} m_{c} \zeta_{i-a-c}
$$

where $m_{c}$ is cation molality, $m_{a}$ is anion molality, and $\lambda_{i-c}, \lambda_{i-a}$, and $\zeta_{i-a-c}$ are parameters that are functions of temperature and pressure. $\lambda_{i-c}, \lambda_{i-a}$, and $\zeta_{i-a-c}$ are known as Pitzer parameters and they are usually estimated from gas solubility data from aqueous solutions with dissolved salts. In this work, Pitzer parameters are usually calibrated from gas solubility from $\mathrm{NaCl}$ solutions. $\lambda_{i-\mathrm{Cl}^{-}}$is assumed to be 0 . As the approximation in Duan and Sun [14] and Duan et al. [16], $\lambda_{i \text {-monovalent }}$ and $\lambda_{i \text {-bivalent }}$ are estimated as $\lambda_{i-\mathrm{Na}^{+}}$and $2 \lambda_{i-\mathrm{Na}^{+}}$. All ternary parameters are estimated as $\zeta_{i-\mathrm{Na}-\mathrm{Cl}}$. Pitzer parameters are listed in Table 4.

2.4. Model Validation. The model performance is evaluated from comparison of model results and related experimental data of $\mathrm{CO}_{2}-\mathrm{CH}_{4}$-brine systems (including the subsystems).

For $\mathrm{CO}_{2}-\mathrm{H}_{2} \mathrm{O}-\mathrm{NaCl}$ systems, the experimental studies [17-19] are sufficient, which cover temperature from $0^{\circ} \mathrm{C}$ to more than $250^{\circ} \mathrm{C}$ and pressure from 1 bar to more than 1500 bar. From our comparison, the average absolute derivations for most of the data points are less than $10 \%$. Figures 1(a) and 1 (b) show a comparison of $\mathrm{CO}_{2}$ solubilities in pure water and $\mathrm{NaCl}$ solutions calculated from this model and related experimental data. We can find that the model solutions agree with the experimental data in the wide ranges of temperature, pressure, and salinity. Figure 1 (c) shows the $\mathrm{H}_{2} \mathrm{O}$ solubility in nonaqueous $\left(\mathrm{CO}_{2}\right.$-rich) phase of the model solutions and experimental data. From the figure, the model can well reproduce $\mathrm{H}_{2} \mathrm{O}$ solubility in nonaqueous phase.

Experimental data of $\mathrm{CH}_{4}-\mathrm{H}_{2} \mathrm{O}-\mathrm{NaCl}$ system are also sufficient with temperature from 0 to more than $250^{\circ} \mathrm{C}$ and pressure from 1 bar to more than 1500 bar [20]. Figures 2(a) and 2(b) show the comparison of $\mathrm{CH}_{4}$ solubilities in water and $\mathrm{NaCl}$ solutions of experimental data and this model. Figure 2(c) shows the experimental data of $\mathrm{H}_{2} \mathrm{O}$ in nonaqueous $\left(\mathrm{CH}_{4}\right.$-rich) phase and the related model solutions. From the comparisons, the experimental data can be well reproduced by the model.

Compared with single gas $\left(\mathrm{CO}_{2}\right.$ or $\left.\mathrm{CH}_{4}\right)$-brine systems, gas mixture $\left(\mathrm{CO}_{2}\right.$ and $\mathrm{CH}_{4}$ existing at the same time)-brine systems have less experimental data. The existing data are also not systematic. Qin et al. [21] have studied phase equilibria for $\mathrm{CO}_{2}-\mathrm{CH}_{4}-\mathrm{H}_{2} \mathrm{O}$ system at $325 \mathrm{~K}$ and $376 \mathrm{~K}$ and with pressure from 100 bar to 500 bar. 21 data points were generated in the work. We compared their results with our model. From the comparison (see Figure 3), we can conclude that the model can predict mutual solubilities for $\mathrm{CO}_{2}-\mathrm{CH}_{4}-\mathrm{H}_{2} \mathrm{O}$ system.

In summary, the comparison of the model solutions with existing experimental data shows that the model can well reproduce and predict mutual solubility data of $\mathrm{CO}_{2}-\mathrm{CH}_{4}$ brine systems in wide ranges of temperature, pressure, and salinity. The model is reliable to be used in gas-water-mineral equilibrium analysis.

\section{3. $\mathrm{CO}_{2} / \mathrm{CH}_{4}$-Water-Mineral Interactions in Deep Environments}

In Sichuan basin, carbonates (such as dolomite or calcite) are the dominant minerals in some natural gas reservoirs; meanwhile sulfates (such as gypsum or anhydrite) and clay minerals are also commonly found $[22,23]$. In Sichuan natural gas reservoirs, $\mathrm{CH}_{4}$ is always accompanied with other components such as $\mathrm{CO}_{2}, \mathrm{~N}_{2}$, or $\mathrm{H}_{2} \mathrm{~S}$ [24]. PHREEQC is a famous software package for water-mineral interaction calculations. Pressure effects can be considered using its third version [4]. With an accurate mutual solubility model of $\mathrm{CO}_{2}-\mathrm{CH}_{4}$-brine systems, geochemical reactions in $\mathrm{CO}_{2}-\mathrm{CH}_{4}$-water-mineral systems can be calculated by combining this model and the PHREEQC functionality. Through this research, we aim to find out

(i) the influences on geochemical reactions in depth (i.e., temperature and pressure increase or decrease);

(ii) sensitivity of gas components (i.e., $\mathrm{CO}_{2}$ or $\mathrm{CH}_{4}$ ) to water composition, mineral dissolution, or precipitation.

In this work, the calculations are based on Sichuan basin background. The hydrostatic pressure is assumed to be $100 \mathrm{bar} / \mathrm{Km}$, and geothermal gradient is assumed as $25^{\circ} \mathrm{C} / \mathrm{Km}$ according to a previous work [25] with surface temperature set as $25^{\circ} \mathrm{C}$. The depth range of the research is from $3000 \mathrm{~m}$ to $6000 \mathrm{~m}$. Relationships of depth, temperature, and pressure are shown in Figure 4. To clarify the influences from gas components, sodium chlorite is considered as the only salt that is dissolved in water as an initial solution. Geochemistry equilibrium of $\mathrm{CO}_{2}-\mathrm{CH}_{4}$-brine-dolomite, $\mathrm{CO}_{2}-\mathrm{CH}_{4}$-brinecalcite, and $\mathrm{CO}_{2}-\mathrm{CH}_{4}$-brine-gypsum/anhydrite systems is studied. Two gas compositions are considered, pure $\mathrm{CH}_{4}$ or $10 \% \mathrm{CO}_{2}+90 \% \mathrm{CH}_{4}$, to evaluate $\mathrm{CO}_{2}$ influences.

Table 5 lists the species of ions, minerals, and gases which get involved in geochemical reactions in $\mathrm{CO}_{2}-\mathrm{CH}_{4}$-brinecarbonate systems and $\mathrm{CO}_{2}-\mathrm{CH}_{4}$-brine-sulfate systems.

3.1. $\mathrm{CO}_{2}-\mathrm{CH}_{4}$-Brine-Carbonate Systems. For $\mathrm{CO}_{2}-\mathrm{CH}_{4}-$ brine-carbonate systems, cases of fluid equilibrium with calcite and dolomite are studied, respectively. Figure 5 shows the molality of carbon (including $\mathrm{HCO}_{3}{ }^{-}, \mathrm{CO}_{2}, \mathrm{CaHCO}_{3}{ }^{+}$, $\mathrm{CaCO}_{3}, \mathrm{CO}_{3}{ }^{2-}, \mathrm{MgHCO}_{3}{ }^{-}$, and $\mathrm{MgCO}_{3}$ ) dissolved in aqueous phase with different depths, gas compositions, and salinities. Figure 6 shows the molality of calcium (including $\mathrm{Ca}^{2+}, \mathrm{CaCO}_{3}, \mathrm{CaHCO}_{3}{ }^{+}$, and $\mathrm{CaOH}^{+}$) and magnesium 
TABLE 4: Pitzer parameters for activity coefficients.

\begin{tabular}{lc}
\hline Parameters & Equations \\
\hline$\lambda_{\mathrm{CO}_{2}-\mathrm{Na}^{+}}$ & $-3.1312239 \times 10^{-1}+5.532647 \times 10^{-4} \mathrm{~T}+7.5844401 \times 10^{1} / T-1.8950519 \times 10^{-4} \mathrm{P}+7.1628762 \times 10^{-5} \mathrm{P} / \mathrm{T}-1.458572 \times 10^{-8} \mathrm{P}^{2} \mathrm{~T}$ \\
$\lambda_{\mathrm{CH}_{4}-\mathrm{Na}^{+}}$ & $-5.7066455 \times 10^{-1}+7.2997588 \times 10^{-4} \mathrm{~T}+1.5176903 \times 10^{2} / \mathrm{T}+3.1927112 \times 10^{-5} \mathrm{P}-1.642651 \times 10^{-5} \mathrm{P} / \mathrm{T}$ \\
$\lambda_{\mathrm{H}_{2} \mathrm{~S}-\mathrm{Na}^{+}}$ & $1.03658689-1.1784797 \times 10^{-3} \mathrm{~T}-1.7754826 \times 10^{2} / \mathrm{T}-4.5313285 \times 10^{-4} \mathrm{P}+4.775165 \times 10^{1} \mathrm{P} / \mathrm{T}^{2}$ \\
$\zeta_{\mathrm{CO}_{2}-\mathrm{Na}^{+}-\mathrm{Cl}^{-}}$ & $-1.14462 \times 10^{-2}+2.8274958 \times 10^{-5} \mathrm{~T}+1.3980876 \times 10^{-2} \mathrm{P} / \mathrm{T}-1.4349005 \times 10^{-2} \mathrm{P} /(630-T)$ \\
$\zeta_{\mathrm{CH}_{4}-\mathrm{Na}^{+}-\mathrm{Cl}^{-}}$ & $-2.9990084 \times 10^{-3}$ \\
$\zeta_{\mathrm{H}_{2} \mathrm{~S}-\mathrm{Na}^{+}-\mathrm{Cl}^{-}}$ & $-1.0274152 \times 10^{-2}$ \\
\hline
\end{tabular}

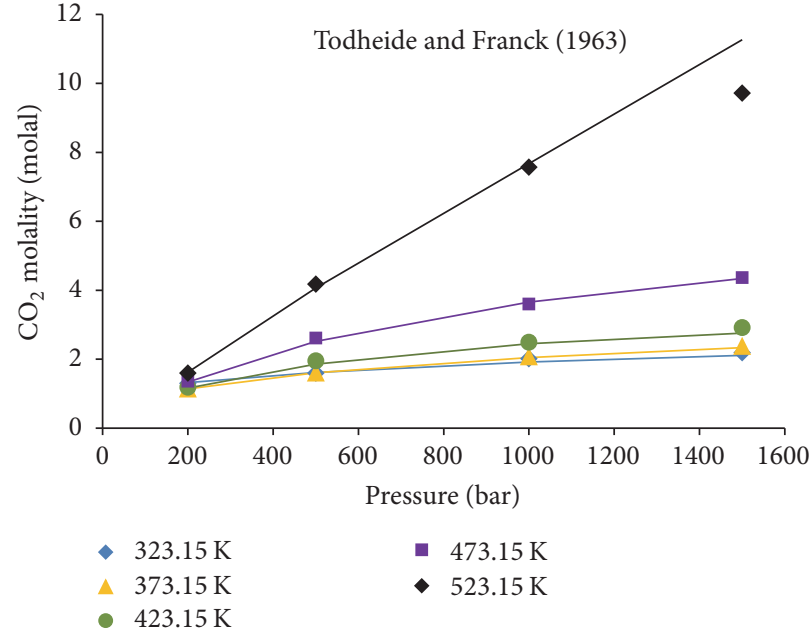

(a)

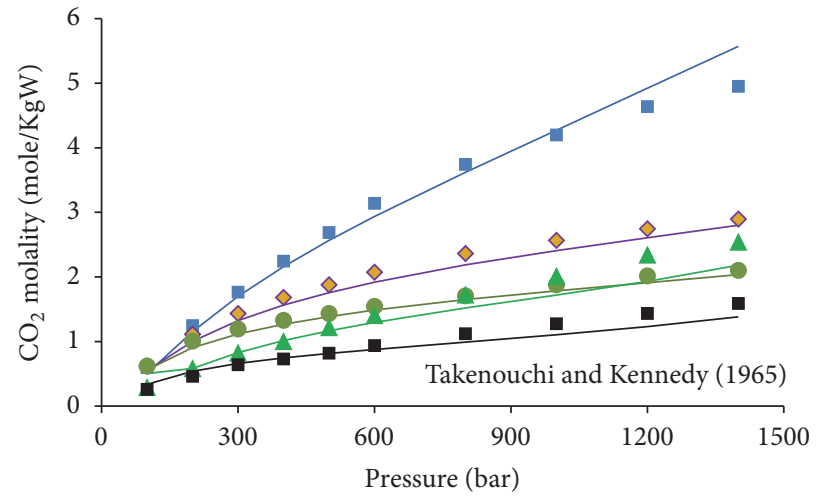

- $523.15 \mathrm{~K}, \mathrm{mNaCl}=1.09$ mole $/ \mathrm{KgW}$

$\diamond 473.15 \mathrm{~K}, \mathrm{mNaCl}=1.09$ mole $/ \mathrm{KgW}$

- $423.15 \mathrm{~K}, \mathrm{mNaCl}=1.09 \mathrm{~mole} / \mathrm{KgW}$

$\Delta 523.15 \mathrm{~K}, \mathrm{mNaCl}=4.28 \mathrm{~mole} / \mathrm{KgW}$

- $423.15 \mathrm{~K}, \mathrm{mNaCl}=4.28 \mathrm{~mole} / \mathrm{KgW}$

(b)

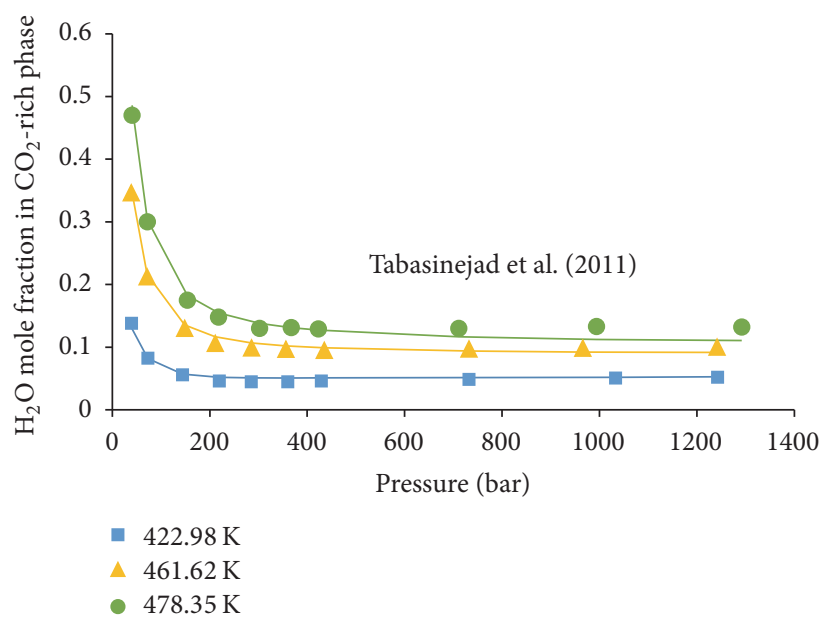

(c)

Figure 1: Mutual solubilities of $\mathrm{CO}_{2}$-brine systems. Lines are calculated results from this model, and dots are from experimental data. (a) $\mathrm{CO}_{2}$ solubility in pure water; (b) $\mathrm{CO}_{2}$ solubility in $\mathrm{NaCl}$ solutions; (c) $\mathrm{H}_{2} \mathrm{O}$ solubility in $\mathrm{CO}_{2}$-rich phase.

(including $\mathrm{Mg}^{2+}, \mathrm{MgOH}^{+}, \mathrm{MgCO}_{3}$, and $\mathrm{MgHCO}_{3}^{+}$) that is dissolved in aqueous phase. From Figure 6, it is shown that $\mathrm{CO}_{2}$ in the gas phase will promote calcite or dolomite dissolution. From the calculations, we find that, with $\mathrm{CO}_{2}$ existing in the system, carbon concentration in aqueous phase increases with depth. From $3000 \mathrm{~m}$ to $6000 \mathrm{~m}$, the carbon molality is almost doubled in Figure 5 at different salinities. However, compared with calcium, magnesium is more solvable and increases with depth. From our calculation, in fluid-dolomite systems, with an increase in 


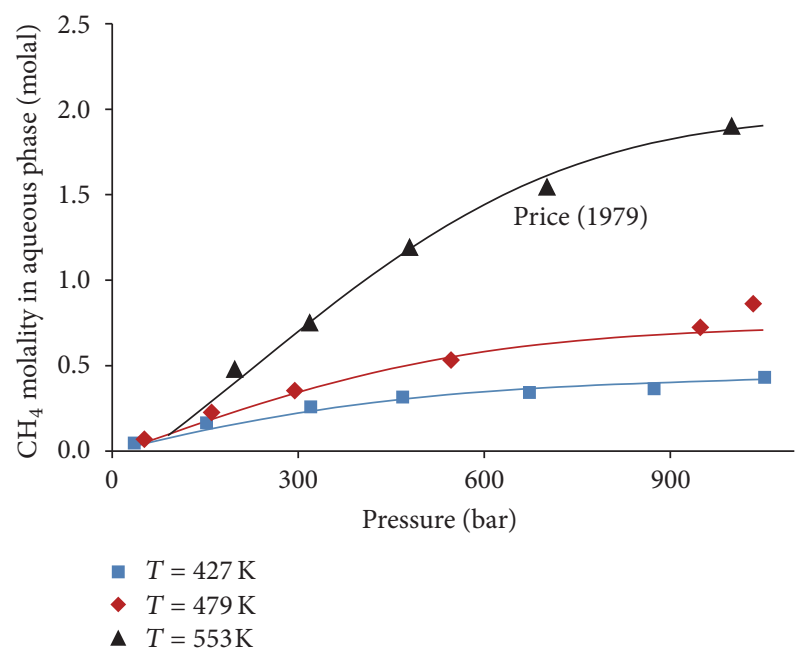

(a)

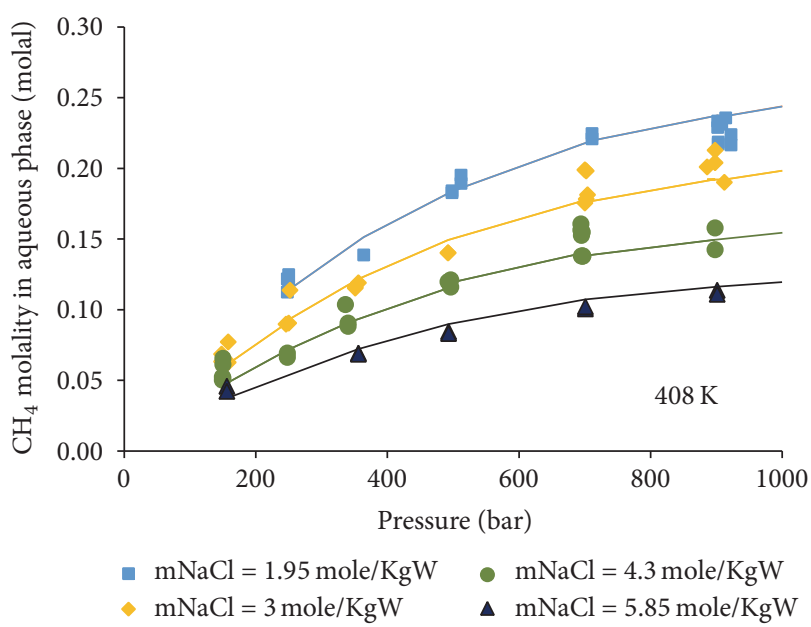

(b)

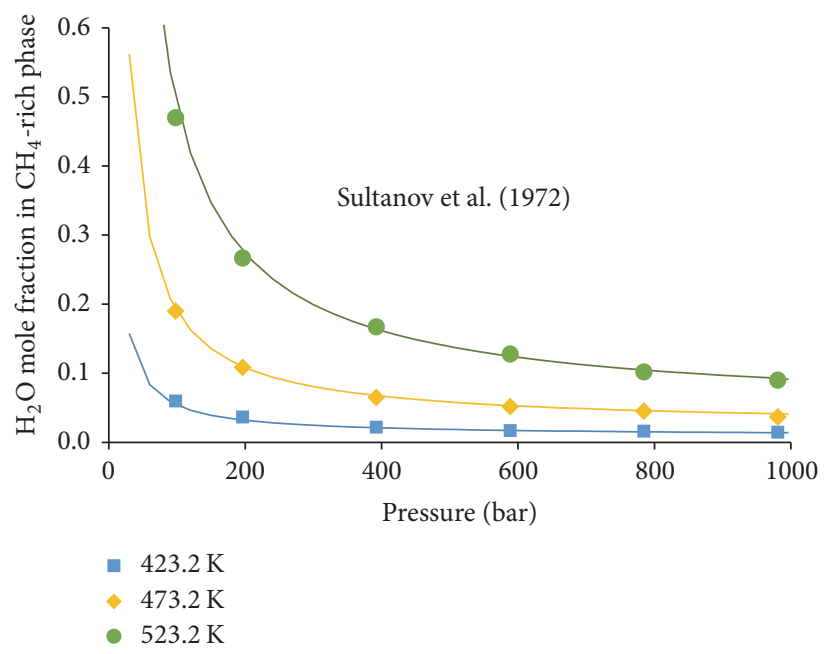

(c)

Figure 2: Mutual solubilities of $\mathrm{CH}_{4}$-brine systems. Lines are calculated results from this model, and dots are from experimental data. (a) $\mathrm{CH}_{4}$ solubility in pure water; (b) $\mathrm{CH}_{4}$ solubility in $\mathrm{NaCl}$ solutions; (c) $\mathrm{H}_{2} \mathrm{O}$ solubility in $\mathrm{CH}_{4}$-rich phase.

temperature and pressure, more calcite precipitates. We can conclude that, in deep carbonate environments, calcium is more likely to precipitate and magnesium ion is more likely to be rich in aqueous phase and transport to shallower areas due to diffusion gradient. So, in general, calcite approaches being existing in deeper environments and dolomite is more likely to be existing in shallower environments.

3.2. $\mathrm{CO}_{2}-\mathrm{CH}_{4}$-Brine-Sulfate Systems. The element sulfur can have different chemical valences such as $-2,0,+4$, and +6 in nature. When sulfates are dissolved in water, sulfur is usually in +6 valence state. It could be reduced to other valence states when reducer exists in the solution. In deep gas reservoirs in Sichuan basin, sulfates commonly exist. Different fluid compositions may trigger different redox geochemical reactions and lead to different forms of sulfur or even reservoir properties.
In this work, we perform several numerical experiments to evaluate the influence of gas composition and depth on fluid-mineral equilibrium. For gas composition, we considered three cases: pure $\mathrm{CH}_{4}, 10 \% \mathrm{CO}_{2}+90 \% \mathrm{CH}_{4}$, and pure $\mathrm{CO}_{2}$. The calculations covered depth from $3000 \mathrm{~m}$ to $6000 \mathrm{~m}$. Figure 7 presents $\mathrm{S}(-2)$ (i.e., sulfur dissolved in water with chemical valence -2 , which can be $\mathrm{S}^{2-}, \mathrm{HS}^{-}$, and $\mathrm{H}_{2} \mathrm{~S}$ as ions) and $\mathrm{S}(+6)$ (i.e., sulfur dissolved in water in chemical valence +6 , which can be $\mathrm{SO}_{4}{ }^{2-}, \mathrm{HSO}_{4}{ }^{-}, \mathrm{CaSO}_{4}$, and $\mathrm{CaHSO}_{4}{ }^{+}$) concentration in equilibrium of gas-water-gypsum. From Figure 7, we can find the following:

(1) With pure $\mathrm{CO}_{2}$ in gas, $\mathrm{S}(-2)$ in water is extremely low, and more $\mathrm{CH}_{4}$ is dissolved in water leading to higher $\mathrm{S}(-2)$ concentration.

(2) Higher $\mathrm{CO}_{2}$ mole fraction in gas phase will lead to higher $\mathrm{S}(+6)$ concentration in water phase. 

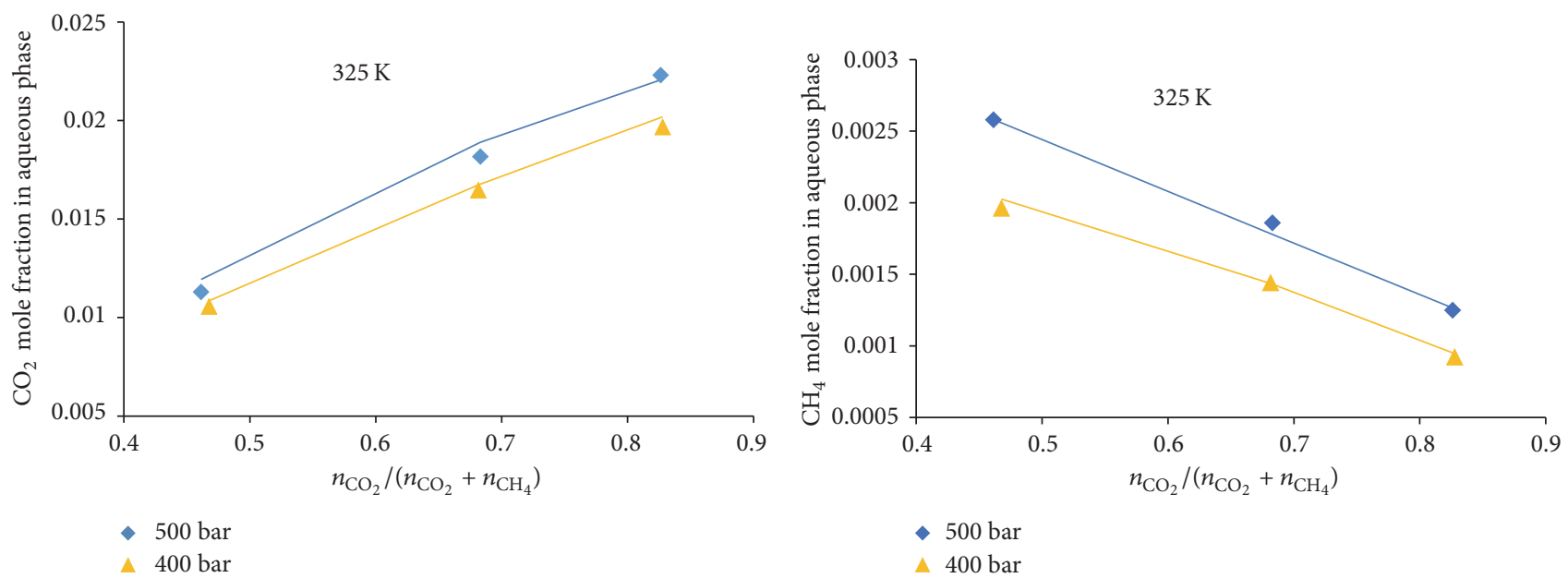

(a)
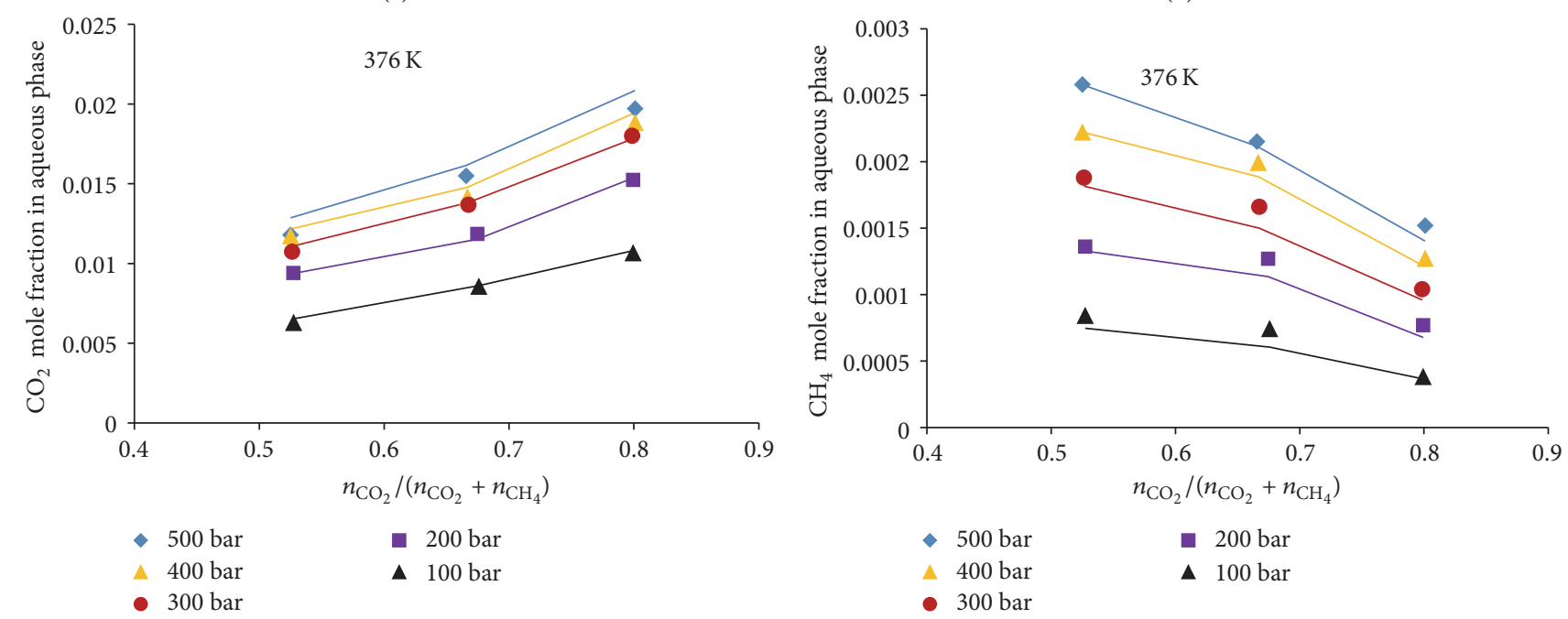

(c)

(d)

Figure 3: $\mathrm{CO}_{2} / \mathrm{CH}_{4}$ solubilities in water in $\mathrm{CO}_{2}-\mathrm{CH}_{4}-\mathrm{H}_{2} \mathrm{O}$ systems at different temperature and pressure. Dots are from Qin et al.'s [21] experimental data, and lines are from this model.
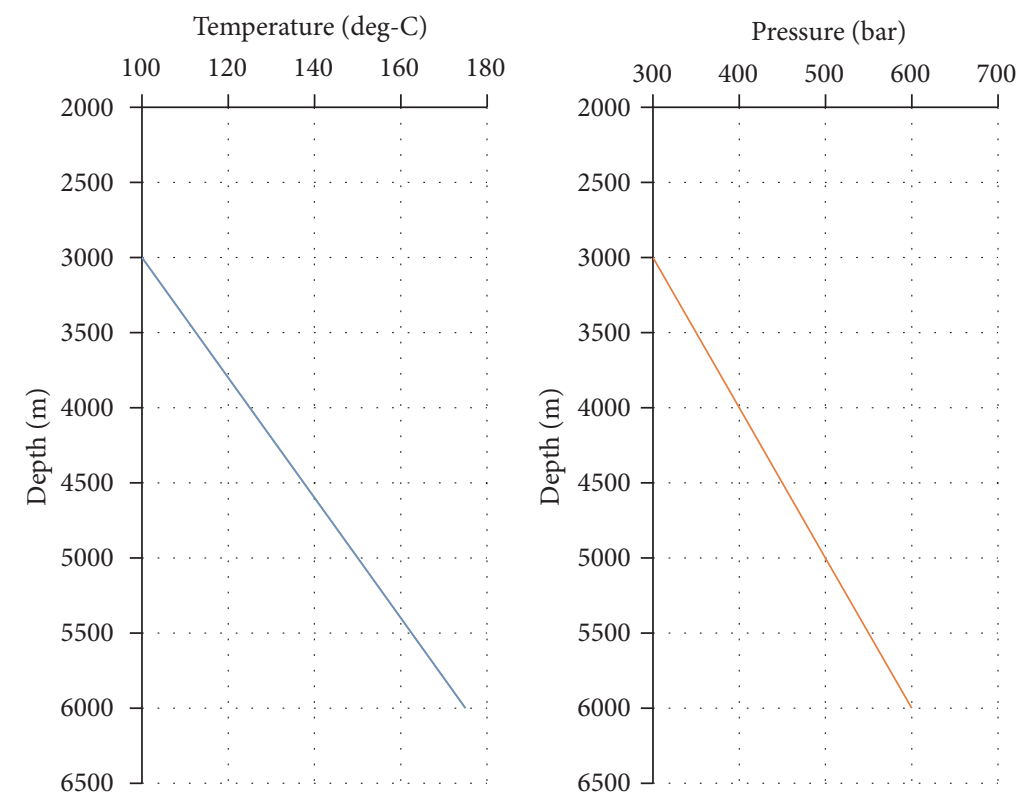

FIgURE 4: Temperature, pressure, and depth relationships. 
TABLE 5

(a) Ions, minerals, and gases involved in $\mathrm{CO}_{2}-\mathrm{CH}_{4}$-brine-carbonate systems

\begin{tabular}{lccc}
\hline Cations & Anions & Neutral ions & Minerals and gases \\
\hline $\mathrm{H}^{+}$ & $\mathrm{OH}^{-}$ & $\mathrm{H}_{2} \mathrm{O}$ & Aragonite \\
$\mathrm{Ca}^{2+}$ & $\mathrm{HCO}_{3}{ }^{-}$ & $\mathrm{CH}_{4}$ & Calcite \\
$\mathrm{CaHCO}_{3}{ }^{+}$ & $\mathrm{CO}_{3}{ }^{2-}$ & $\mathrm{CO}_{2}$ & Dolomite \\
$\mathrm{CaOH}^{+}$ & $\mathrm{Cl}^{-}$ & $\left(\mathrm{CO}_{2}\right)_{2}$ & Halite \\
$\mathrm{Mg}^{2+}$ & $\mathrm{NaCO}_{3}{ }^{-}$ & $\mathrm{CaCO}_{3}$ & $\mathrm{CH}_{4}(\mathrm{~g})$ \\
$\mathrm{MgHCO}_{3}{ }^{+}$ & & $\mathrm{H}_{2}$ & $\mathrm{CO}_{2}(\mathrm{~g})$ \\
$\mathrm{MgOH}^{+}$ & & $\mathrm{MgCO}_{3}$ & $\mathrm{H}_{2}(\mathrm{~g})$ \\
$\mathrm{Na}^{+}$ & & $\mathrm{NaHCO}_{3}$ & $\mathrm{H}_{2} \mathrm{O}(\mathrm{g})$ \\
& & $\mathrm{NaOH}_{2}$ & $\mathrm{O}_{2}(\mathrm{~g})$ \\
& & $\mathrm{O}_{2}$ & \\
\hline
\end{tabular}

(b) Ions, minerals, and gases involved in $\mathrm{CO}_{2}-\mathrm{CH}_{4}$-brine-sulfate systems

\begin{tabular}{lccc}
\hline Cations & Anions & Neutral ions & Minerals and gases \\
\hline $\mathrm{H}^{+}$ & $\mathrm{OH}^{-}$ & $\mathrm{H}_{2} \mathrm{O}$ & Anhydrite \\
$\mathrm{Ba}^{2+}$ & $\mathrm{HCO}_{3}{ }^{-}$ & $\mathrm{BaSO}_{4}$ & Aragonite \\
$\mathrm{BaHCO}_{3}{ }^{+}$ & $\mathrm{NaCO}_{3}{ }^{-}$ & $\mathrm{BaCO}_{3}$ & Barite \\
$\mathrm{BaOH}^{+}$ & $\mathrm{CO}_{3}{ }^{2-}$ & $\mathrm{NaHCO}_{3}$ & Calcite \\
$\mathrm{CaHCO}_{3}{ }^{+}$ & $\mathrm{Cl}^{-}$ & $\mathrm{CaCO}_{3}$ & Dolomite \\
$\mathrm{MgHCO}_{3}{ }^{+}$ & $\mathrm{NaSO}_{4}{ }^{-}$ & $\left(\mathrm{CO}_{2}\right)_{2}$ & Gypsum \\
$\mathrm{Ca}^{2+}$ & $\mathrm{HS}^{-}$ & $\mathrm{MgCO}_{3}$ & Halite \\
$\mathrm{CaHSO}_{4}{ }^{+}$ & $\mathrm{S}^{2-}$ & $\mathrm{CaSO}_{4}$ & Sulfur \\
$\mathrm{CaOH}^{+}$ & $\mathrm{SO}_{4}{ }^{2-}$ & $\mathrm{MgSO}_{4}$ & Witherite \\
$\mathrm{Mg}^{2+}$ & $\mathrm{HSO}_{4}{ }^{-}$ & $\mathrm{NaOH}_{2}$ & $\mathrm{H}(\mathrm{g})$ \\
$\mathrm{MgOH}^{+}$ & & $\mathrm{O}_{2}$ & $\mathrm{H}_{2} \mathrm{O}(\mathrm{g})$ \\
$\mathrm{Na}^{+}$ & & $\mathrm{H}_{2} \mathrm{~S}$ & $\mathrm{H}_{2} \mathrm{~S}(\mathrm{~g})$ \\
& & $\mathrm{H}_{2}$ & $\mathrm{O}_{2}(\mathrm{~g})$ \\
& & $\mathrm{CH}_{4}$ & $\mathrm{CH}_{4}(\mathrm{~g})$ \\
& & $\mathrm{CO}_{2}$ & $\mathrm{CO}_{2}(\mathrm{~g})$ \\
\hline
\end{tabular}

(3) With higher depth, higher $\mathrm{S}(+6)$ concentration can be found, but depth influence on $S(-2)$ concentration is not clear.

It is clear that $\mathrm{CH}_{4}$ is the key component for $\mathrm{S}(+6)$ to be reduced to $S(-2)$ species in water. The related redox geochemical reaction is

$$
\mathrm{SO}_{4}{ }^{2-}+\mathrm{CH}_{4} \longleftrightarrow \mathrm{CO}_{3}{ }^{2-}+\mathrm{S}^{2-}+2 \mathrm{H}^{+}+\mathrm{H}_{2} \mathrm{O}
$$

When $\mathrm{CH}_{4}$ and $\mathrm{SO}_{4}{ }^{2-}$ are dissolved in water, the above reaction is triggered, and $\mathrm{CH}_{4}$ is oxidized from $\mathrm{C}(-4)$ to $\mathrm{C}(+4)$. In the meantime, $\mathrm{SO}_{4}{ }^{2-}$ is reduced to $\mathrm{S}^{2-}$.

Figure 8(a) shows the amount of calcite precipitation for different cases of geochemical equilibrium. Referring to Figure $8(\mathrm{a})$, in case of pure $\mathrm{CO}_{2}$ in gas phase, there is no calcite precipitation; with higher $\mathrm{CH}_{4}$ mole fraction in gas phase, more calcite can be precipitated; in deeper environments, more calcite can be precipitated. This phenomenon is also connected with sulfur reduction. With $\mathrm{CH}_{4}$ dissolved in water, more sulfate is consumed and more calcium ions are dissolved in water. In this process, carbanions are generated because of the redox reaction. With more and more calcium

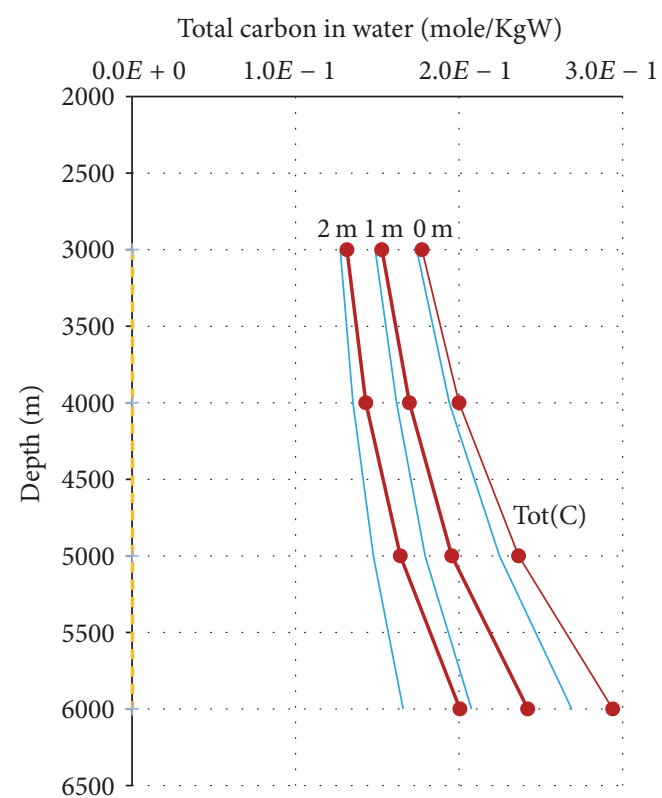

FIGURE 5: Molality of total carbon dissolved in water varying with depth at different salinities and gas compositions. Dashed yellow line represents the case of pure $\mathrm{CH}_{4}$ of gas in the system. Blue lines represent results from fluid-calcite systems (with gas composition $\mathrm{CO}_{2}: \mathrm{CH}_{4}=1: 9$ in mole). Red lines with dots represent the result from fluid-dolomite systems (with gas composition $\mathrm{CO}_{2}: \mathrm{CH}_{4}=1: 9$ in mole).

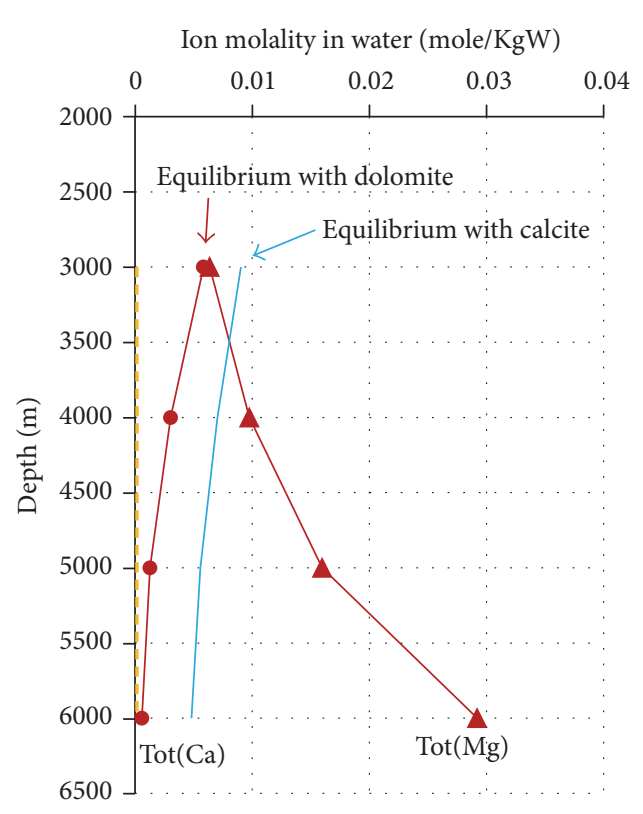

FIGURE 6: Molality of elements $\mathrm{Ca}$ and $\mathrm{Mg}$ dissolved in water varying with depth (with sodium chlorite molality 0 ). Yellow line represents the case of pure $\mathrm{CH}_{4}$ of gas in the system. Red lines with dots represent results from fluid-dolomite systems (with gas composition $\mathrm{CO}_{2}: \mathrm{CH}_{4}=1: 9$ in mole). Blue line represents results from fluidcalcite systems (with gas composition $\mathrm{CO}_{2}: \mathrm{CH}_{4}=1: 9$ in mole). 


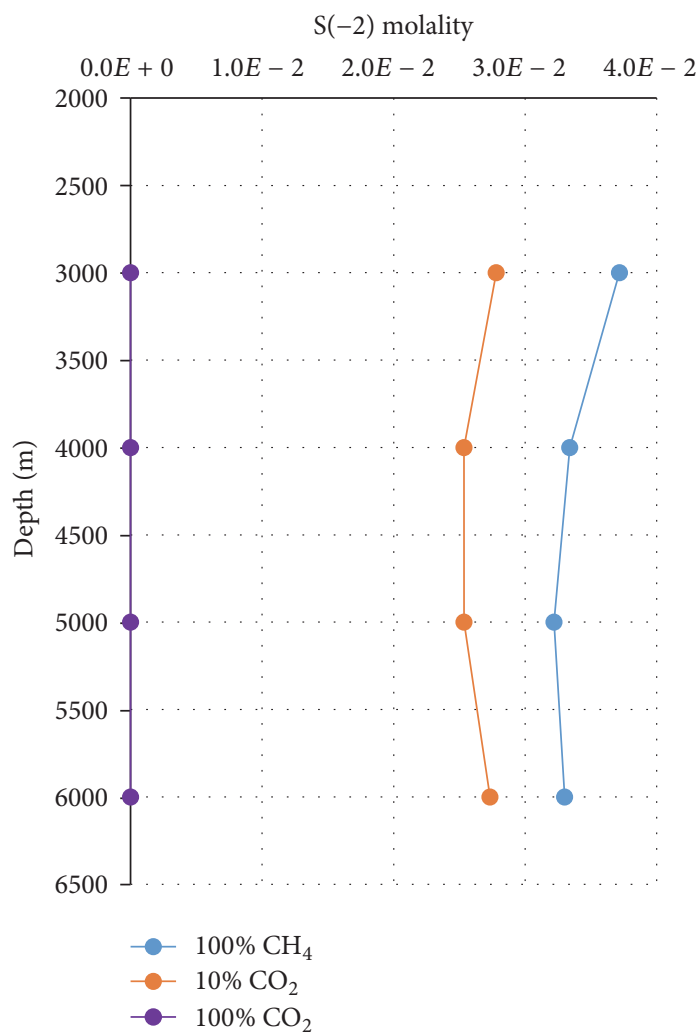

(a)

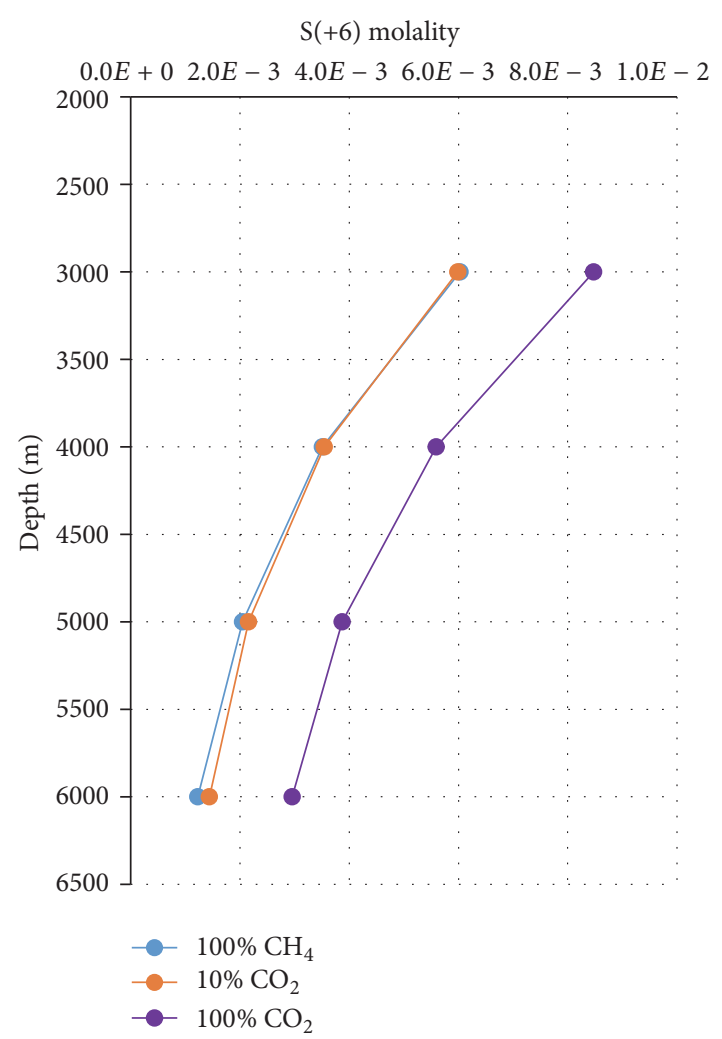

(b)

FIGURE 7: Concentration of $\mathrm{S}(+6)$ and $\mathrm{S}(-2)$ in aqueous phase varying with depth in equilibrium of gas $\left(\mathrm{pure}^{\mathrm{C}} \mathrm{H}_{4}, 10 \% \mathrm{CO}_{2}+90 \% \mathrm{CH}_{4}\right.$, or pure $\mathrm{CO}_{2}$ ), water, and gypsum.

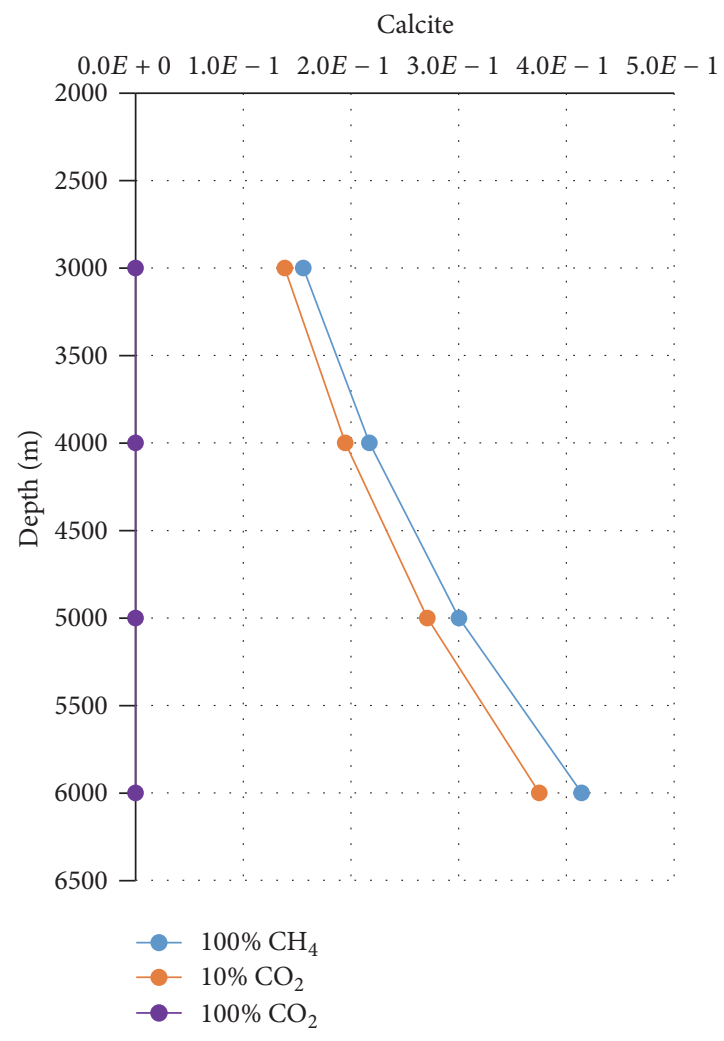

(a)

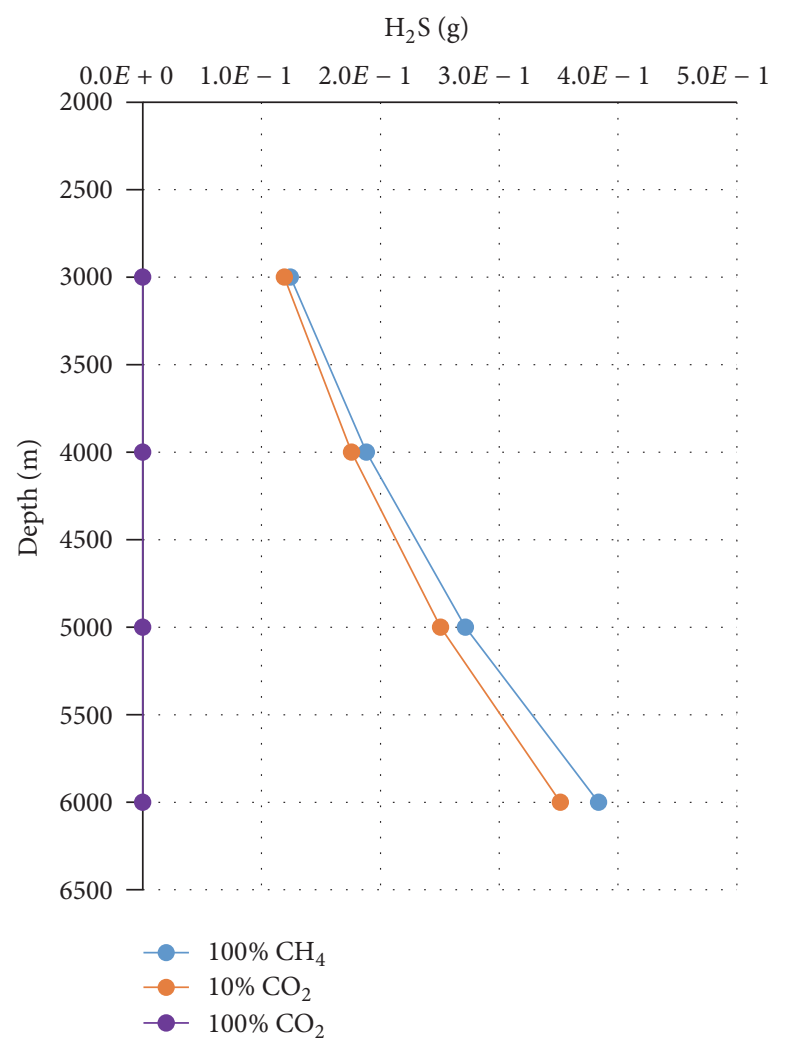

(b)

FIGURE 8: (a) Mole number of calcite precipitated and (b) mole number of $\mathrm{H}_{2} \mathrm{~S}$ released to gas with $1 \mathrm{KG}$ water in equilibrium with gas (pure $\mathrm{CH}_{4}, 10 \% \mathrm{CO}_{2}+90 \% \mathrm{CH}_{4}$, or pure $\mathrm{CO}_{2}$ ) and gypsum at different depths. 
and carbanion in the solution, calcite becomes saturated and precipitates. Another product is $\mathrm{H}_{2} \mathrm{~S}$ in gas phase. With more and more $\mathrm{S}(-2)$ generated in water, $\mathrm{S}^{2-}$ and $\mathrm{H}^{+}$approach combining with one another, and $\mathrm{H}_{2} \mathrm{~S}$ becomes saturated and is released in gas phase. As shown in Figure 8(b), with more $\mathrm{CH}_{4}$ in gas phase, more $\mathrm{H}_{2} \mathrm{~S}$ will be generated in gas phase at equilibrium states. From this study, we can find that $\mathrm{CH}_{4}$ water-sulfate redox reaction could be a mechanism of $\mathrm{H}_{2} \mathrm{~S}$ origin in gas reservoirs [2]. From the figure, we can also find that, at higher depth, more $\mathrm{H}_{2} \mathrm{~S}$ can be generated. This result agrees with the statement from $\mathrm{Li}$ et al. [2].

\section{Conclusions}

In this work, an accurate mutual solubility model is constructed with "fugacity-activity" method for $\mathrm{CO}_{2}-\mathrm{CH}_{4}$-brine systems. This model has a wide application range of pressure, temperature, and salinity, which can be used for fluid phase equilibrium in deep hydrocarbon reservoirs.

Combined with the mutual solubility model and PHREEQC, the equilibrium $\mathrm{CO}_{2}-\mathrm{CH}_{4}$-brine-mineral systems under deep reservoir conditions can be calculated. The mutual solubility model can be used to calculate the mole numbers of $\mathrm{CO}_{2} / \mathrm{CH}_{4}$ dissolved in brine at given temperature, pressure, and salinity. With the dissolved mole numbers of $\mathrm{CO}_{2} / \mathrm{CH}_{4}$, PHREEQC is used to calculate the speciation between aqueous phase and mineral.

$\mathrm{CO}_{2} / \mathrm{CH}_{4}$-brine-carbonate (i.e., dolomite or calcite) and $\mathrm{CO}_{2} / \mathrm{CH}_{4}$-brine-sulfate (i.e., gypsum or anhydrite) equilibria were studied with the above methodology. From the study, we find the following:

(1) For $\mathrm{CO}_{2} / \mathrm{CH}_{4}$-brine-carbonate (calcite or dolomite) systems, with an increase in depth, calcium is more likely to precipitate as calcite and magnesium is more likely dissolved in aqueous phase. In other words, dolomite could be rich in shallower position and calcite may approach being existing at deeper locations.

(2) With $\mathrm{CH}_{4}$ present in the $\mathrm{CO}_{2} / \mathrm{CH}_{4}$-brine-sulfate (gypsum or anhydrite) systems, redox reaction is triggered and $\mathrm{S}(+6)$ is reduced to $\mathrm{S}(-2) . \mathrm{H}_{2} \mathrm{~S}$ will be released when $S(-2)$ becomes saturated in aqueous phase. This process could be one of the origins for $\mathrm{H}_{2} \mathrm{~S}$ in gas reservoirs in Sichuan basin, China.

This work is an attempt to do preliminary fluid-mineral interaction calculations with a new established accurate mutual solubility model of $\mathrm{CO}_{2}-\mathrm{CH}_{4}$-brine systems combined with PHREEQC, version 3 . The geochemical reaction parameters are still needed to be validated for high temperature and pressure. Also, more systematic research work of gas-water-minerals is still required in the future according to real depositional environments.

\section{Conflicts of Interest}

The authors declare that there are no conflicts of interest regarding the publication of this paper.

\section{Acknowledgments}

This work is supported by National Natural Science Foundation of China (Grant no. 41502246). Dimue Tech. Ltd. Co. provided technical support during the research. The authors also acknowledge the sponsorship from National Key R\&D Program of China (2016YFE0102500).

\section{References}

[1] G. Zhu and S. Zhang, "Hydrocarbon accumulation conditions and exploration potential of deep reservoirs in China," Actc Petrolei Sinica, vol. 30, no. 10, 2009 (Chinese).

[2] K. Li, C. Cai, D. Hou et al., "Origin of high $\mathrm{H}_{2} \mathrm{~S}$ concentrations in the Upper Permian Changxing reservoirs of the Northeast Sichuan Basin, China," Marine and Petroleum Geology, vol. 57, pp. 233-243, 2014.

[3] H. G. Machel, H. R. Krouse, and R. Sassen, "Products and distinguishing criteria of bacterial and thermochemical sulfate reduction," Applied Geochemistry, vol. 10, no. 4, pp. 373-389, 1995.

[4] D. L. Parkhurst and C. A. J. Appelo, Description of Input and Examples for PHREEQC Version 3 - A Computer Program for Speciation, Batch-Reaction, One-Dimensional Transport, and Inverse Geochemical Calculations, U.S. Geological Survey Techniques and Methods, 2013.

[5] T. Xu, N. Spycher, E. Sonnenthal, G. Zhang, L. Zheng, and K. Pruess, "TOUGHREACT version 2.0: a simulator for subsurface reactive transport under non-isothermal multiphase flow conditions," Computers and Geosciences, vol. 37, no. 6, pp. 763774,2011

[6] J. Li, L. Wei, and X. Li, "An improved cubic model for the mutual solubilities of $\mathrm{CO}_{2}-\mathrm{CH}_{4}-\mathrm{H}_{2} \mathrm{~S}$-brine systems to high temperature, pressure and salinity," Applied Geochemistry, vol. 54, pp. 1-12, 2015.

[7] J. Li, Z. Zhang, X. Luo, and X. Li, "Modelling of phase equilibria in $\mathrm{CH}_{4}-\mathrm{C}_{2} \mathrm{H}_{6}-\mathrm{C}_{3} \mathrm{H}_{8}-n \mathrm{C}_{4} \mathrm{H}_{10}-\mathrm{NaCl}-\mathrm{H}_{2} \mathrm{O}$ systems," Applied Geochemistry, vol. 56, pp. 23-36, 2015.

[8] J. Li and Z. Duan, "A thermodynamic model for the prediction of phase equilibria and speciation in the $\mathrm{H}_{2} \mathrm{O}-\mathrm{CO}_{2}-\mathrm{NaCl}$ $\mathrm{CaCO}_{3}-\mathrm{CaSO}_{4}$ system from 0 to $250 \circ \mathrm{C}, 1$ to 1000 bar with $\mathrm{NaCl}$ concentrations up to halite saturation," Geochimica et Cosmochimica Acta, vol. 75, no. 15, pp. 4351-4376, 2011.

[9] D.-Y. Peng and D. B. Robinson, "A new two-constant equation of state," Industrial Engineering Chemistry Fundamentals, vol. 15, pp. 59-64, 1976.

[10] I. Søreide and C. H. Whitson, "Peng-Robinson predictions for hydrocarbons, $\mathrm{CO}_{2}, \mathrm{~N}_{2}$, and $\mathrm{H}_{2} \mathrm{~S}$ with pure water and $\mathrm{NaCI}$ brine," Fluid Phase Equilibria, vol. 77, no. C, pp. 217-240, 1992.

[11] K. S. Pitzer, "Thermodynamics of electrolytes. I. theoretical basis and general equations," Journal of Physical Chemistry, vol. 77, no. 2, pp. 268-277, 1973.

[12] C. E. Harvie, N. Møller, and J. H. Weare, "The prediction of mineral solubilities in natural waters: The $\mathrm{Na}-\mathrm{K}-\mathrm{Mg}-\mathrm{Ca}-\mathrm{H}-\mathrm{Cl}-$ $\mathrm{SO}_{4}-\mathrm{OH}-\mathrm{HCO}_{3}-\mathrm{CO}_{3}-\mathrm{CO}_{2}-\mathrm{H}_{2} \mathrm{O}$ system to high ionic strengths at 25॰C," Geochimica et Cosmochimica Acta, vol. 48, no. 4, pp. 723-751, 1984.

[13] J. P. Greenberg and N. Møller, “The prediction of mineral solubilities in natural waters: A chemical equilibrium model for the $\mathrm{Na}-\mathrm{K}-\mathrm{Ca}-\mathrm{Cl}-\mathrm{SO}_{4}-\mathrm{H}_{2} \mathrm{O}$ system to high concentration from 0 to $250 \circ$ C," Geochimica et Cosmochimica Acta, vol. 53, no. 10, pp. 2503-2518, 1989. 
[14] Z. Duan and R. Sun, "An improved model calculating $\mathrm{CO}_{2}$ solubility in pure water and aqueous $\mathrm{NaCl}$ solutions from 273 to $533 \mathrm{~K}$ and from 0 to 2000 bar," Chemical Geology, vol. 193, no. 3-4, pp. 257-271, 2003.

[15] Z. Duan and D. Li, "Coupled phase and aqueous species equilibrium of the $\mathrm{H}_{2} \mathrm{O}-\mathrm{CO}_{2}-\mathrm{NaCl}-\mathrm{CaCO}_{3}$ system from 0 to 250॰C, 1 to 1000 bar with $\mathrm{NaCl}$ concentrations up to saturation of halite," Geochimica et Cosmochimica Acta, vol. 72, no. 20, pp. 5128-5145, 2008.

[16] Z. Duan, N. Møller, and J. H. Weare, "An equation of state for the $\mathrm{CH}_{4}-\mathrm{CO}_{2}-\mathrm{H}_{2} \mathrm{O}$ system: I. Pure systems from 0 to $1000 \circ \mathrm{C}$ and 0 to 8000 bar," Geochimica et Cosmochimica Acta, vol. 56, no. 7, pp. 2605-2617, 1992.

[17] K. Tödheide and E. U. Franck, "Das zweiphasengebiet und die kritische kurve im system kohlendioxid-wasser bis zu drucken von 3500 bar," Zeitschrift fur Physikalische Chemie, vol. 37, no. 5-6, pp. 387-401, 1963.

[18] S. Takenouchi and G. C. Kennedy, "The solubility of carbon dioxide in $\mathrm{NaCl}$ solutions at high temperatures and pressures," American Journal of Science, vol. 263, no. 5, pp. 445-454, 1965.

[19] F. Tabasinejad, R. G. Moore, S. A. Mehta et al., "Water solubility in supercritical methane, nitrogen, and carbon dioxide: Measurement and modeling from 422 to $483 \mathrm{~K}$ and pressures from 3.6 to $134 \mathrm{MPa}$,' Industrial and Engineering Chemistry Research, vol. 50, no. 7, pp. 4029-4041, 2011.

[20] R. G. Sultanov, V. G. Skripka, and A. Y. Namoit, "Phase equilibrium and critical effect of water-methane system under increased temperature and pressure," Zhurnal Fizicheskoi Khimi, vol. 46, p. 2160, 1972.

[21] J. Qin, R. J. Rosenbauer, and Z. Duan, "Experimental measurements of vapor-liquid equilibria of the $\mathrm{H}_{2} \mathrm{O}+\mathrm{CO}_{2}+\mathrm{CH}_{4}$ ternary system," Journal of Chemical and Engineering Data, vol. 53, no. 6, pp. 1246-1249, 2008.

[22] H. Wen, L. Wen, H. Chen, R. Zheng, L. Dang, and Y. Li, "Geochemical characteristics and diagenetic fluids of dolomite reservoirs in the Huanglong Formation, Eastern Sichuan Basin, China," Petroleum Science, vol. 11, no. 1, pp. 52-66, 2014.

[23] C. Liu, Q. Xie, G. Wang et al., "Rare earth element characteristics of the carboniferous Huanglong Formation dolomites in eastern Sichuan Basin, southwest China: implications for origins of dolomitizing and diagenetic fluids," Marine and Petroleum Geology, vol. 81, pp. 33-49, 2017.

[24] S. Qin, G. Zhou, W. Li, Y. Hou, and F. Lü, "Geochemical evidence of water-soluble gas accumulation in the Weiyuan gas field, Sichuan Basin," Natural Gas Industry B, vol. 3, no. 1, pp. 37-44, 2016.

[25] Y. Han and C. Wu, "Geothermal gradient and heat flow values of some deep wells in sichuan basin," Oil Gas Geology, vol. 14, pp. 80-84, 1993. 

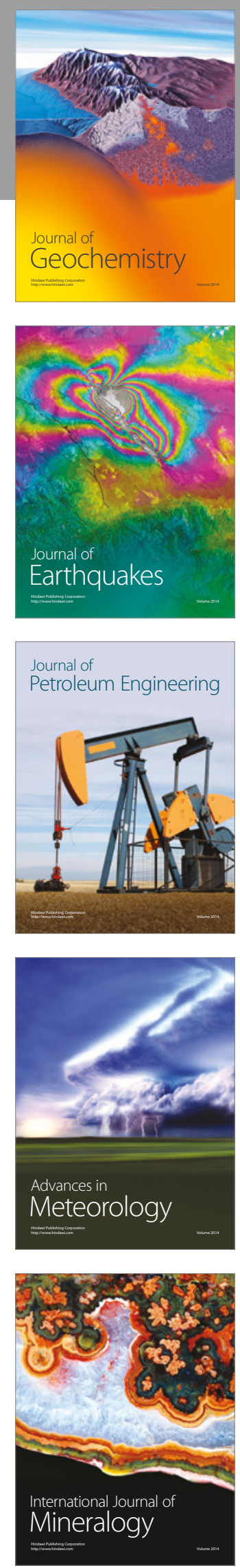
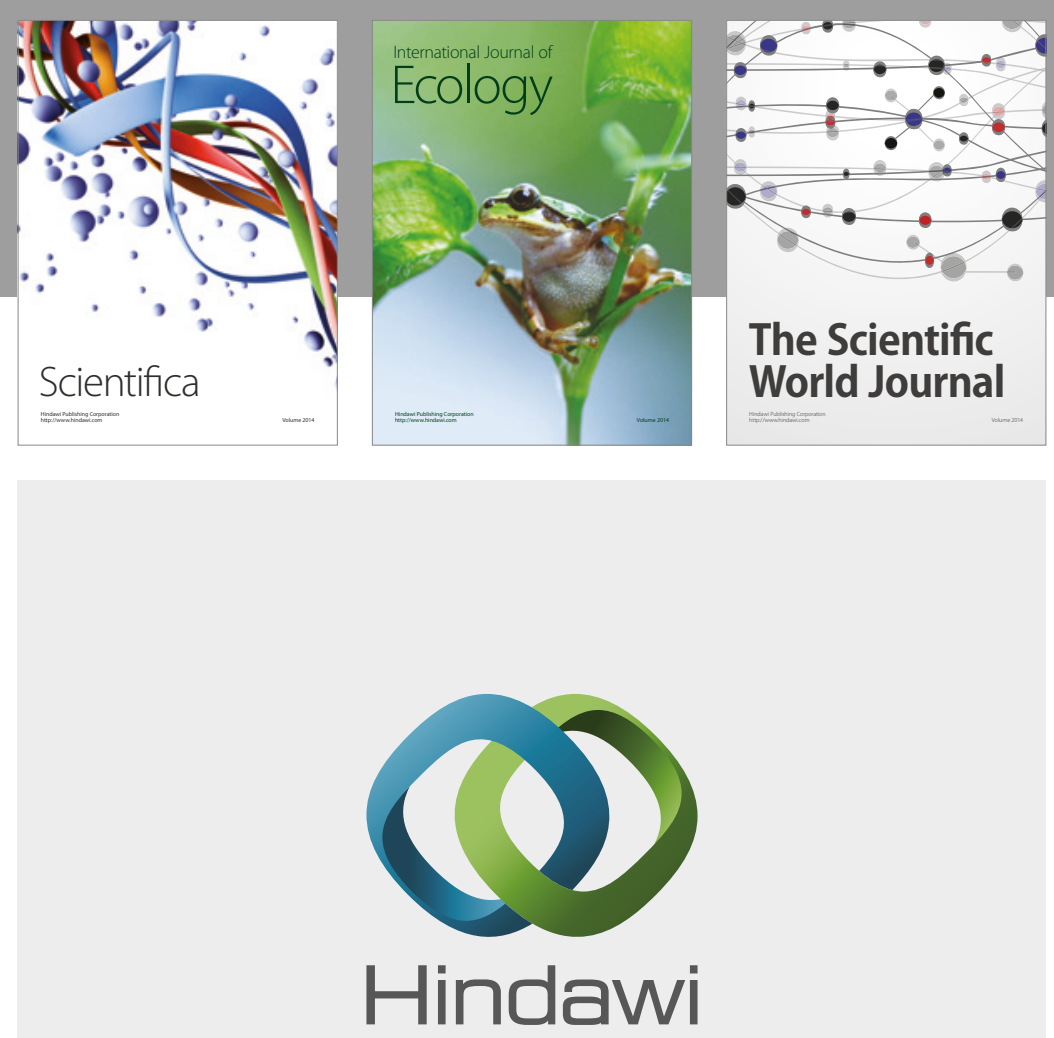

Submit your manuscripts at

https://www.hindawi.com
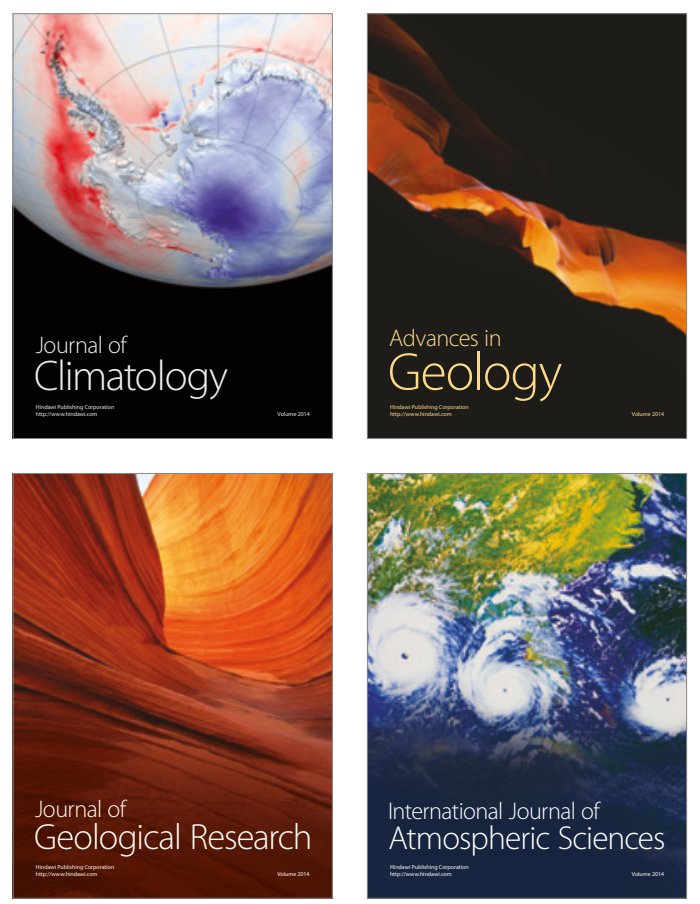

The Scientific

World Journal
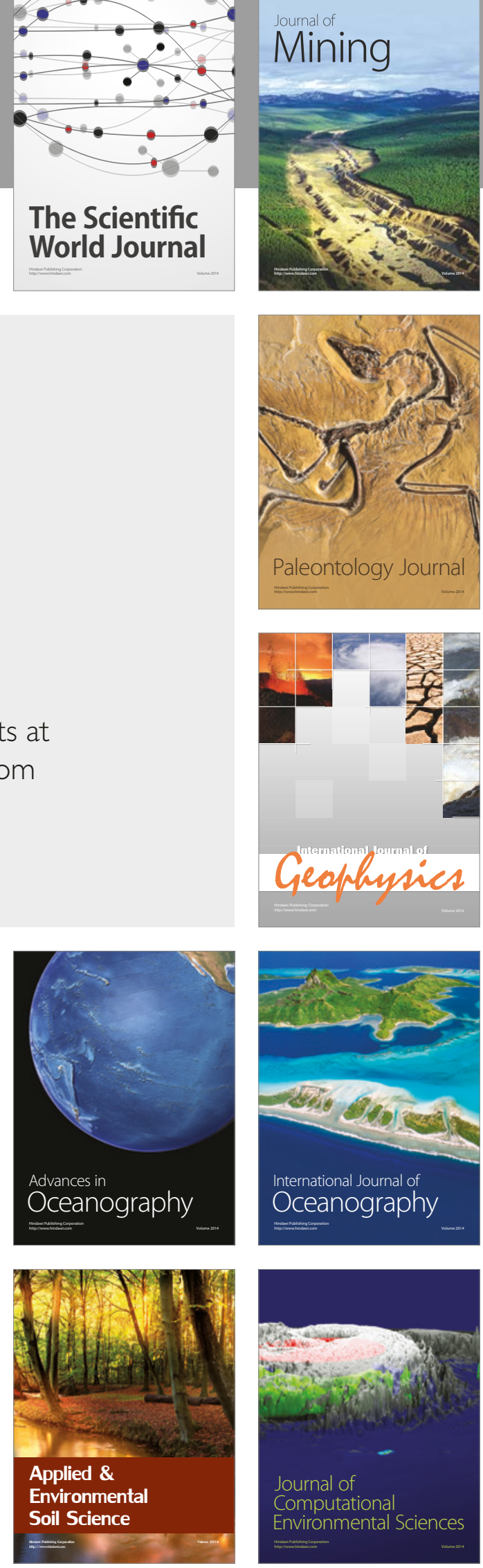